\title{
Teaching the teacher program to assist nurse managers to educate nursing staff in Ecuadorian hospitals
}

Sheri P. Palmer

Brigham Young University - Provo, sheri_palmer@byu.edu

Sondra Heaston

Brigham Young University - Provo

Follow this and additional works at: https://scholarsarchive.byu.edu/facpub

Part of the Other Nursing Commons, and the Public Health and Community Nursing Commons

\section{Original Publication Citation}

Palmer, S., \& Heaston, S., \& Movius, C.* (2009). Teaching the Teacher Program to Assist Nurse Managers to Educate Nursing Staff in the Ecuadorian Hospitals, Nursing Education in Practice, 9, 127-133.

\section{BYU ScholarsArchive Citation}

Palmer, Sheri P. and Heaston, Sondra, "Teaching the teacher program to assist nurse managers to educate nursing staff in Ecuadorian hospitals" (2008). Faculty Publications. 5327.

https://scholarsarchive.byu.edu/facpub/5327

This Peer-Reviewed Article is brought to you for free and open access by BYU ScholarsArchive. It has been accepted for inclusion in Faculty Publications by an authorized administrator of BYU ScholarsArchive. For more information, please contact ellen_amatangelo@byu.edu. 


\title{
Teaching the teacher program to assist nurse managers to educate nursing staff in Ecuadorian hospitals
}

\author{
Sheri P. Palmer *, Sondra Heaston ${ }^{1}$
}

Corey Movius, Baccalaureate Student Nurse, Brigham Young University, College of Nursing, Box 500, SWKT Provo, UT 84062, United States

Accepted 10 October 2008

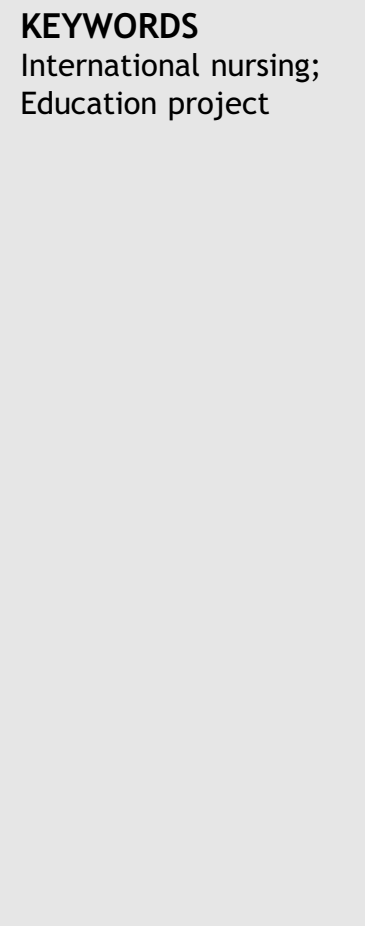

\begin{abstract}
Summary Continuing education for hospital staff nurses is a concern worldwide. Current research shows that continuing education among nurses can positively affect patient outcomes (O'Brien, T., Freemantle, N., Oxman, A, et al., 2002. Interactive continuing education workshops or conferences can improve professional practice and patient outcomes. Journal of Evidence Based Nursing. 26 (5)). Seeing a need for improved patient outcomes among hospitals in Ecuador, we conducted a teaching the teacher program to assist nurse managers to carry-out continuing education in their hospital system. This teaching the teacher program was established through the collaboration between one College of Nursing in Utah, USA and a large healthcare system in Guayaquil, Ecuador. The collaboration has been ongoing for five years, 2003 to present. Initial projects included classes for the nursing staff including technical skills, life-saving techniques, and nursing process and assessment. Collaborators from the US and Ecuador believed that in order to maximize the improvement of nursing care in the hospital system it was necessary to turn attention on the nurse managers and not just the staff nurses. This would allow for meaningful ongoing learning beyond the one-time classroom setting. Continuing education is not common in Ecuadorian hospitals as it is in the United States. The purpose of this paper is to describe the project and provide initial evaluative data on the response to the curriculum; including evidence of managers using the teaching principles they were taught. The underlying aim of the project was to achieve a sustainable impact by teaching the leaders of each unit how to be more effective teachers.

In May 2007, a two-day "teaching the teacher" workshop was developed with the needs of the managers in mind. The participants in the course included the chief
\end{abstract}

\footnotetext{
Corresponding author. Tel.: +1 8014221306.

E-mail addresses: sheri-palmer@byu.edu, sondra-heaston@byu.edu

1 Tel.: +1 8014221210 .
} 
nursing officer and leaders of various units of the hospital. In May 2008 a follow-up class was taught, along with an evaluation by a verbal and written survey with open ended questions and an observation of an actual class being taught by the participants.

(C) 2008 Elsevier Ltd. All rights reserved.

\section{Introduction}

With patient outcomes and continuing education being a concern worldwide, the main purpose of this paper is to discuss an ongoing needs assessment and program development to improve nursing continuing education within Ecuador. As educators, we believe that education is a valuable resource one can provide to another. Our belief is that increased education will bring about positive change, and this will ultimately affect patient outcomes. This principle has seen little change over the past decade in international nursing (Leinonen, 2006; Oswalt and Boyce, 2000; O'Toole et al., 1996).

International nursing experiences are widely varied, yet highlighted as an influential piece of one's nursing career. A common thread throughout many foreign collaborations is the hope that each party will come away changed for the better. The universal goal of change for improvement is the driving force for many international programs (Fang, 2008; Leinonen, 2006; McAuliffe and Cohen, 2005; Oswalt and Boyce, 2000). This goal of improvement may even be the catalyst for sustainability of a program. Indeed, these authors agree that both sides of the collaboration must see benefit for a relationship to continue. Our experience with an international program has been challenging, yet rewarding. A few years of work and experiences have shown success and built international camaraderie.

Ecuador is located in South America at the equator. It is bordered on the west by the Pacific Ocean, north by Columbia, and south by Peru. It is a developing country about the size of Arizona with varied geographic regions. The population is about 13 million with $30.4 \%$ below the international poverty line. There is a mix of urban, rural, indigenous, and refugee people in Ecuador. Over the past few years refugees and rural populations have migrated to neighborhoods around the few large urban cities. These areas are homes to thousands and are deficient in basic resources such as potable water and sanitation.

In Ecuador, poverty is directly impacted by years of political and social problems. Health care is a privilege as much of the health care expenditure is out of pocket. Twenty to thirty percent of Ecua- dor's population have no access to health care, with $75 \%$ not having access to institutional health services through a social security system. Public spending on health care also has declined from $1.1 \%$ in 1995 to $0.5 \%$ in 1999 . Typically, per capita spending on health care has been one of the lowest in South America. (PAHO, Profile of the Health Services System of Ecuador, 2001) This trend of decreasing health care economics and availability also affects the health care workforce of the country. Low wages, labor instability and unemployment are constant challenges among health workers. (PAHO, 2004) Furthermore, assessment of quality of care and accreditation of health care services is still in its infancy in the country. (PAHO, Profile of the Health Services System of Ecuador, 2001).

Nursing in Ecuador has been stymied by the health care trends of the country. Furthermore, continuing nursing education is recognized as a critical priority on the nursing development agenda in the Americas (Malvarez and Castrillon, 2005). Upon reflection of our 5-year affiliation with many nurses in Ecuador we've noticed that the self-perception of the worth of a nurse is low, however the basic values and characteristics of the nurse remain altruistic in nature. Ecuadorian nurses are happy with their profession, yet they feel frustrated with their jobs. Global health research is an essential part of providing development in all sectors of health care. This concept can be the foundation for all international nursing exchanges and relationships. (McAuliffe and Cohen, 2005) The relationship of "good" nursing to positive patient outcomes is key to enhancing the health care society.

Recognizing the need for research in international nursing education is essential. Many articles review issues and successes of nursing students having experiences in other countries (Levine and Perpetua, 2006; Caffrey et al., 2005; Lee, 2004; Ryan and Twibell, 2002), yet little research has been done on sharing education to better nurses internationally. In a literature review by McAuliffe and Cohen (2005) there are increased recent efforts in developing nursing research and education in other countries. They point out that developing countries received only $10 \%$ of health care research 
and funding while developed countries receive $90 \%$. This gap is further pronounced with the fact that most of the health research conducted is for the benefit of wealthier countries (Global Forum for Health Research, 2000).

Within the last two years of our international experience we have taught a class to nursing managers of a large hospital in Guayaquil, Ecuador entitled "Teaching the Teachers." Continuing education is not a commonality in this system and not an expectation for the personnel. The desire of the administration to increase education among the healthcare workers was the impetus to build future teachers that can carry on this focus of education. It was hoped that attendance at the "Teach the teacher" program and the mentoring of managers could maximize the manager's goal of providing valuable continuing nursing education.

\section{Needs assessment}

The Ecuador Project has been part of a clinical experience in the Global Health and Diversity class within the College of Nursing at Brigham Young University for the last 5 years. The instigation of this project began when La Junta de Beneficencia (The Group of Benefactors) was referred to our college of nursing as a possibility to assist in teaching their nursing personnel. This has proved a valuable international relationship for many students and faculty. Four large hospitals are owned by The Junta de Beneficencia in Ecuador, which is the largest non-government organization in the country. These hospitals include an Adult General Hospital, Pediatric Hospital, Maternity Hospital, and Psychiatric Hospital. The General Hospital was the first healthcare facility in Ecuador to be awarded the ISO 9001:2000 International Certification, meaning that the hospital complies with international standards for quality management systems (http://en. jbg.org.ec/docs/statistics/hospitals/ieh_jbg.pdf). The hospital system is making unprecedented strides in caring for the needy of Ecuador, and is actively seeking for help in improving patient outcomes.

A needs assessment within the general hospital was conducted at the start of the collaboration. From the outset, the educators from the United States have been careful in making judgments (Buckingham, 1999). The initial assessment was mutually created and implemented by healthcare professionals from Ecuador and the United States. Efforts were taken to accurately assure the needs of the country and hospital system were the driving force behind the project (McAuliffe and Cohen,
2005). As is acutely seen, the number of nurses available in the country of Ecuador is far less than in the United States (See Fig. 1). Our experience in Ecuador has shown that the average hospital nurse has little time or resources to pursue furthering their own education. Taking into account the shortage of nurses within the hospital and the country, Ecuadorian leaders and US professionals determined that continuing education for the available nurses in the hospital system would have the greatest lasting effect on improving patient outcomes.

Through the needs assessment, a three-step plan was developed to help improve patient outcomes and nursing care within the hospitals owned by the Junta de Beneficencia. The three steps included: (1) assessment of needed teaching, (2) implementation and teaching, and (3) re-assessment with recommendations and training for the hospitals to continue on their own. The project is currently in its' third phase with re-assessment and training being a continual process. (See Fig. 2 for Project Chronology).

Through the years the continuing education classes given by the joint efforts of students and faculty provided by the Brigham Young University College of Nursing have been well attended and highly successful. However, it was evident that these hospitals could become dependent on others to do their education. Thus, the last planned phase of the Ecuador Project (Reassessment and Training) was imperative in helping the hospitals become self-reliant in their continuing education. As seen in the timeline, a "Teaching the Teachers" class was added in 2007. The goal of this class was to improve the self-sufficiency of nurse leaders in providing continuing education among personnel that work in the targeted hospital system in Guayaquil, Ecuador.

\begin{tabular}{|l|l|l|l|}
\hline Country & Population & Nurses/1,000 & $\begin{array}{l}\text { Hospital } \\
\text { beds/1,000 }\end{array}$ \\
\hline Ecuador & 13,003 million & 0.5 & 1.5 \\
\hline Peru & 27,167 million & 0.67 & 1.8 \\
\hline Venezuela & 25,699 million & 0.79 & 2 \\
\hline $\begin{array}{l}\text { United } \\
\text { States }\end{array}$ & 305,284 million & 7.53 & 2.75 \\
\hline
\end{tabular}

Figure 1 Comparison of nurses/hospital beds in South America and United States of America.<http://www. paho.org/english/dd/ais/cp_218.htm>, <http://woodrow. mpls.frb.fed.us/research/data/specmap/us07-01.cfm> 


\begin{tabular}{|c|c|c|c|}
\hline Year & Phase & Accomplishments & $\begin{array}{c}\text { Group of US and } \\
\text { Ecuadorian } \\
\text { Collaborators }\end{array}$ \\
\hline 2003 & $\begin{array}{l}\text {-Assessment of } \\
\text { needed teaching }\end{array}$ & -Initial visit & -3 person team \\
\hline 2004 & $\begin{array}{l}\text {-Implementation of } \\
\text { teaching }\end{array}$ & $\begin{array}{l}\text {-Several courses } \\
\text { and nursing skills } \\
\text { were taught }\end{array}$ & $\begin{array}{l}\text {-Faculty, graduate } \\
\text { nursing students, } \\
\text { and alumni of the } \\
\text { nursing program }\end{array}$ \\
\hline 2005 & $\begin{array}{l}\text {-Implementation of } \\
\text { teaching } \\
\text {-Re-assessment }\end{array}$ & $\begin{array}{l}\text {-Student nurses } \\
\text { worked side by side } \\
\text { Ecuadorian nurses } \\
\text { in hospitals. } \\
\text {-Courses taught in } \\
\text { hospitals }\end{array}$ & $\begin{array}{l}\text {-Faculty, } \\
\text { undergraduate and } \\
\text { graduate nursing } \\
\text { students }\end{array}$ \\
\hline 2007 & $\begin{array}{l}\text {-Implementation of } \\
\text { teaching } \\
\text {-Reassessment }\end{array}$ & $\begin{array}{l}\text {-Student nurses } \\
\text { worked side by side } \\
\text { with Ecuadorian } \\
\text { nurses in the } \\
\text { hospital } \\
\text {-Teaching in the } \\
\text { hospital } \\
\text {-Teaching nurse } \\
\text { leaders -"Teaching } \\
\text { the teachers" } \\
\text { course. }\end{array}$ & $\begin{array}{l}\text {-Faculty, } \\
\text { undergraduate and } \\
\text { graduate nursing } \\
\text { students }\end{array}$ \\
\hline 2008 & $\begin{array}{l}\text {-Implementation of } \\
\text { teaching } \\
\text {-Reassessment }\end{array}$ & $\begin{array}{l}\text {-Student nurses } \\
\text { worked side by side } \\
\text { with Ecuadorian } \\
\text { nurses in the } \\
\text { hospitals } \\
\text {-Teaching in the } \\
\text { hospitals } \\
\text {-"Teaching the } \\
\text { teacher" course } \\
\text { part Il in the hospital }\end{array}$ & $\begin{array}{l}\text {-Faculty and } \\
\text { undergraduate } \\
\text { nursing students }\end{array}$ \\
\hline
\end{tabular}

Figure 2 Chronology of Ecuador visits.

\section{Program description}

The foundation for the "Teaching the Teacher" class is based on the educational theory by Cohen (1987). The three foci of a learning cycle (goals, teaching activities, and assessment) were explained in class. The concepts were analyzed through discussion and the importance of each in contribution to learning was well understood. The three areas were discussed further with the following actions:

(1) actual goals were made, based upon perceived needs of each department;

(2) learning activities and strategies were delineated, resources for teaching materials were shown, and up-to-date knowledge attainment explained;

(3) feedback and assessment techniques were discussed, and plans to implement this phase were instituted.

In May 2007, a two-day workshop was developed with the needs of the nurse leaders in mind. Funding was provided by a mentoring grant through Brigham Young University. The partici- pants in the course included the chief nursing officer and seven managers of various units of the general hospital. The participants of this class learned about the three parts of teaching which include goals, methods and evaluation. With the input of education needs from the nursing managers, a class schedule was developed that would cover the basics of education, and the needs of the hospital and nurses. Highlights of the course were: basic steps of teaching; exercises in critical thinking; organizing lectures; test-question writing; and developing effective lesson plans. We spent time teaching about how to find current information via the internet and how to construct power point presentations. We were very sensitive to the idea that our way was not the only way to do things and did our best to assess and present content that was applicable. The nurse leaders set departmental goals, plans for achievement, outlined teaching strategies, and learned to evaluate and write effective test questions. The class was successful and dynamic. They expressed eagerness to follow-through with their plans and felt that improvements were not just a wish, but were indeed within their grasp. 
In May 2008, participants from the prior years' class were sought out by contacting nursing administration. Data was collected via questionnaire, interview, and an observation checklist with a group of seven former participants to assess the quality of the educational program. Fluent Spanish speakers trained in qualitative questioning conducted the interviews. An observation of a class taught by one of the participants from the "Teaching the Teacher"' classes was also conducted. Seventy-five percent of the prior years' class was able to be interviewed. Data was collected through identifying common themes from the questions in the interview of the participants. This was done by incorporating qualitative analysis methods outlines (Miles and Huberman, 1994) which looks for common themes in the data. Demographic data was also analyzed by simple statistics.

\section{Program results}

Demographic results of the subjects showed that the average age of the nurse leader was 43 (range of 36-48 years) with a SD 4.082. The average length of time being a nurse is 16 years (range of 12-20 years) with a SD 2.944, with an average of 4 years (range of $2-10$ years) as a nurse leader (supervisor or manager) with a SD 2.683. Half of the subjects work only in their leadership position, while the other half also work as a nurse in another area of the hospital.

The questionnaire given asked the participants view of the concepts, goals, and impressions of the "Teaching the Teacher" class. (See Fig. 3) The survey also asked the nurse leaders their perception of the importance of continuing nursing education. The responses given varied a great deal, however a common theme included the desire to be a knowledgeable leader, who can assist the nurses in their unit to reach new levels of education and to put into practice what they learned. Some of the statements and goals concerning continuing education in nursing were as follows: "I want to practice what I learned;" "I realized the importance of training and updated information. When you teach you need up-to-date information;" "I want to reproduce what I learned;" and finally, "I received strength through the knowledge taught."

As stated earlier, the purpose of the class was to improve the participants' knowledge and ability to proceed with continuing nursing education. This concept emerged because of the concern that the staff would become reliant on outside teaching rather than going forward themselves. Two of the nurse leaders in the study highlighted the same concern when questioned about their perceived challenges in continuing nursing education. One stated that it was hard to establish protocols and execute them correctly because there is a lack of professionalism among the nurses. The second participant said that it was a challenge to find someone within the hospital that was qualified to teach. These comments seemed to support the need for the "Teaching the Teacher" class.

One of the challenges noted by two of the nurse leaders was the unwillingness of some personnel to change or to have the desire to change. They expressed the thought that in many settings, when things have proceeded in a similar pattern for many years, it is easy to continue in the same manner because of tradition. When new knowledge of a better way emerges, some do not wish to change.

Some of the questions were as follows:

1. What were some of the concepts that were taught in the "Teaching the Teacher" class?

2. What were your teaching goals you set in the "Teaching the Teacher" class?

3. How has the "Teaching the Teacher" class changed your perception of continual education among the nurses in the hospital?

4. How are your teaching goals being instituted?

a. If you have taught a class, how did you determine what to teach?

b. What classes have you taught?

c. How many times did you teach?

d. In what format did you teach?

e. What challenges did you encounter in teaching this class?

f. What were some of the successes in the class?

g. How did you get feedback and evaluate skills?

5. How has the teaching you have done changed the nursing care in your hospital unit?

Figure 3 Questionnaire for "Teaching the Teacher" participants. 
However, two other leaders articulated that the challenge of change is inciting the interest of many people to participate.

As the nurse leaders applied what they learned and began to teach their areas, different methods were employed to select an area to teach. A common method was to choose a topic of personal interest in regards to the unit/area of employment. For example, one leader was a manager over emergency services and was interested in incorporating a "code team" for resuscitation. Although this method of topic selection was evident, other methods were: one nurse chose her topics based on the errors and incorrect procedures done in her department; and another chose her topic by asking the personnel what would be of interest to them.

Six of the nurse leaders have been teaching classes on a routine basis over the past year, many of them numerous times. Two of the leaders had organized a class for new nursing assistants that took place on a daily basis for the period of 6 months. One participant noted that she teaches "continually every day," while other leaders noted they teach in organized classes throughout "different hospitals." In answer to the question of what teaching methods were being used, participants responded by saying they use computers, PowerPoint's, or audiovisuals to teach.

Additional perceived barriers among the nursing leaders/teachers were not being able to institute change due to staff shortages, difficult questions posed in class by students, language barriers, and speaking in front of people. However, according to this project, the successes largely outnumbered the challenges. When asked about their perceived successes in being teachers, the response varied greatly. Five of the leaders made statements regarding their personal growth through the "Teaching the Teachers" class and the subsequent classes they have taught. One overcame her fear of speaking in public and other participants felt satisfaction when they saw improvement in nursing practice or student learning.

\section{Discussion}

This project showed that it is imperative to teach the nurse leaders how to teach. This can help them find current information to be knowledgeable and qualified so that the areas they supervise will have up-to-date information. Increased education and know-how among the nurse leaders will transmit to furthering education and increasing positive patient outcomes within their respective areas of responsibility.
Overall limitations of the project and evaluation include number of participants and challenges inherent in many international educational experiences. Those include cultural differences, language issues, accessibility of technology, relevance of importance, and availability of qualified individuals (Immonen et al., 2008; McAuliffe and Cohen, 2005; Ryan and Twibell, 2002; O'Toole et al., 1996). In analyzing the data from this project, the above mentioned concepts played a role. Interpretation of handwriting and spelling in a different language with qualitative research was difficult to interpret. There were also language differences in understanding the questions. Lastly, a year can be a long time to remember specific points from a class, however it was evident that many of the basic concepts were remembered.

The next step in this international exchange will be to stress the importance of feedback and assessment in teaching with these new leaders. Our plan is to mentor and teach this area of the educational process so they can implement future changes as needed. It will be essential to follow these educators over time to see the long-term effects and multiplicity of education. This project could be replicated in other settings in this country. Other important evaluative components would be to survey the nurses working in the affected units to assess changes in staff practices, their perception of managers teaching, and their personal motivation to learn. Benchmarking of patient outcomes both before and after such intense educational efforts would also be worthwhile.

\section{Conclusion}

International collaborations in nursing can lead to a successful exchange of ideas and experiences. Promoting collaborations that will benefit both vested parties are essential for sustainable and profitable interactions. The Ecuadorian nurse leaders we have worked with are in a position to see firsthand the results of successful continuing education within their hospitals.

Students, nurses, and faculty from the United States that have gone to Ecuador have learned to be adaptable and teachable. Many participants from both countries have voiced that they "learned to practice nursing in a different way." This leads to a wider perspective and increased cultural competence as future nurses. We have learned that "ours" is not the only effective way to practice nursing, and that globally, nurses are essentially the same (Leinonen, 2006). In addition, we have learned that we are of the same heart and 
mind, when it comes to "taking care" of the patient.

History of the Ecuadorian "Teaching the teacher" project shows the foundation of a relationship based on consistency, trust, collegial goals and expectations. We have noticed a change in the enthusiasm amongst these nurse managers to educate their staff. With the last five years of mentoring and teaching future nursing teachers in Ecuador, it is now a real possibility that continuing education among the nurses in this hospital system will become a reality. On the long term, with increased education among the nurses, it is hoped that both nursing practice and patient outcomes will be positively affected.

\section{Acknowledgements}

We would like to acknowledge the Nursing Department of the Junta de Beneficencia of Guayaquil, Ecuador for their collegial cooperation in making this international collaboration successful.

We would like to thank Dr. Gwen Van Servellen for her editorial help.

\section{References}

Buckingham, S., 1999. Elective placements in Romania. Pediatric Nurse 11, 8-9.

Caffrey, R.A., Neander, W., Markle, D., Steward, B., 2005. Improving the cultural competence of nursing students: results of integrating cultural content in the curriculum and an international immersion experience. Journal of Nursing Education. 44 (5), 234-240.

Cohen, S.A., 1987. Instructional alignment: searching for a magic bullet. Educational Researcher, 16-20.

Fang, Y., 2008. The expatriate experience: teaching nursing across Eastern and Western cultures. Journal of Nursing Scholarship 40 (2), 184-187.
Global Forum for Health Research, 2000. The 10/90 Report on Health Research 2000, Global Forum for Health Research, Geneva.

Immonen, I., Anderssen, N., Lvova, M., 2008. Project work across borders in the arctic Barents region: practical challenges for project members. Nurse Education Today 28 (7), 841-848.

Lee, N.-J., 2004. The impact of international experience on student nurses' personal and professional development. International Nursing Review 51, 113-122.

Leinonen, S.J., 2006. International nursing exchange programs. The Journal of Continuing Education in Nursing 37 (1), 16-20.

Levine, M.A., Perpetua, E.M., 2006. International immersion programs in baccalaureate nursing education: professor and student perspectives. Journal of Cultural Diversity 13 (1), 20-26.

Malvarez, S., Castrillon, C., 2005. Overview of the Nursing Workforce in Latin America. Serie Human Resources Development No. 39. Human Resource Development Unit. Strategic Health Development Area. Pan American Health Organization, Washington, DC.

Miles, M.B., Huberman, A.M., 1994. Qualitative Data Analysis, second ed. SAGE Morse, Thousand Oaks, CA.

McAuliffe, M.S., Cohen, M.Z., 2005. International nursing research and educational exchanges: a review of the literature. Nursing Outlook 53 (1), 21-25.

O'Brien, T., Freemantle, N., Oxman, A., et al., 2002. Interactive continuing education workshops or conferences can improve professional practice and patient outcomes. Journal of Evidence Based Nursing 26 (5), Downloaded from ebn.bmj.com on 29 September 2008.

Oswalt, J., Boyce, D., 2000. International nursing education: Istanbul, Turkey. Journal of Pediatric Nursing 15 (3), 183188.

O'Toole, M., Melli, S., Moore, M., Derstine, J., 1996. Global gladiators: a model for international nursing education. Nurse Educator 21 (1), 38-41.

Pan American Health Organization (PAHO), Profile of the Health Services System of Ecuador, 2001, Program on Organization and Management of Health Systems and Services Division of Health Systems and Service Development, second ed., 8 November 2001.

Pan American Health Organization (PAHO), 2004. Epidemiological Bulletin, vol. 25 (2).

Ryan, M., Twibell, R., 2002. Outcomes of a transcultural nursing immersion experience: confirmation of a dimensional matrix. Journal of Transcultural Nursing 13 (1), 30-39. 